\title{
As teses de abril de 2011 sobre educação, consciência de classe e estratégia revolucionária
}

\author{
Celi Nelza Zulke Taffarel*
}

\begin{abstract}
Resumo
O artigo apresenta os principais problemas educacionais do Brasil e suas possíveis soluçôes, na forma de cinco teses. Essas teses foram identificadas após análise da bibliografia pertinente. As teses foram expostas para expressar o conteúdo atual da luta de classes. A conclusão que chegamos é que a função social da escola está em disputa, bem como os rumos da organização dos trabalhadores em educaçáo, sua formaçáo, remuneração, assistência, saúde, previdência. Está em disputa a compreensão do trabalho socialmente útil como princípio educativo e o financiamento da educação. Por fim, são apresentadas as táticas no campo da revoluçáo permanente, ou seja, as táticas para a luta de curto, médio e longo prazo da classe trabalhadora para superar estrategicamente o capitalismo.
\end{abstract}

Palavras-chave: Educação. Consciência de classe. Revolução.

*Doutora em Educação pela Universidade Estadual de Campinas (UNICAMP). Professora titular da Faculdade de Educaçáo (FACED) da Universidade Federal da Bahia (UFBA). 


\section{Anunciando as teses}

Foram delimitadas cinco teses para debater sobre Educação, Consciência de Classe e Estratégia Revolucionária, no interior do V Encontro Brasileiro de Educação e Marxismo ${ }^{1}$, cujo tema central foi Marxismo, Educação e Emancipação Humana.

São cinco teses do campo singular da Educação, colocadas na particularidade da luta dos trabalhadores brasileiros, que se situa na luta mais geral, de caráter internacional, da classe trabalhadora, contra o capital. Colocoas de início, porque são pontos acirrados de disputa entre o projeto burguês e o projeto histórico de escola que a classe trabalhadora defende.

Não podemos olvidar que a revolução é permanente (TROTSKY, 2010)2, e se dá concomitante com processos contra-revolucionários. Caso contrário, não faria sentido nenhum, aqui e agora, reivindicar e festejar os 140 anos da Comuna de Paris $^{3}$, e muito menos as experiências advindas da revolução de outubro de 1917 no leste europeu, que no seu nascedouro nos deixou um legado importantíssimo sobre a Escola Comuna e, muito menos, o legado da Revolução Cubana de 1959.

A linha da história demonstra com fatos que a revolução é permanente e terá atingido seu cume, por veredas abruptas, quando o comunismo estiver instalado no mundo. Coloco-as, pois entendo e defendo que a escola é a forma mais avançada que temos para garantir a formação de crianças, jovens e adultos, no que diz respeito ao acesso ao patrimônio histórico da humanidade e o local privilegiado para desenvolvimento das funçôes psicológicas superiores (VIGOTSKY, 1996) ${ }^{4}$, sem as quais, o processo revolucionário poderá estar comprometido em seu pleno êxito. Isto não contradiz, em absoluta, que existem outros espaços, tempos e sujeitos que exercem o papel de educadores - como, por exemplo, é reivindicado pelos movimentos de luta social no campo ${ }^{5}$, e também como é reivindicado, pelo partido na formação política.

No entanto, a escola continua sendo, o espaço mais avançado para o desenvolvimento da escolarização de crianças, jovens e adultos. Cito-as, pois reconheço expostas em organismos da classe trabalhadora, que muitos decretaram como mortos, reacionários, ou atrasados, dando por acabado um processo em curso, como são as teses defendidas por dentro da Confederação Nacional dos Trabalhadores em Educação (CNTE), filiada a Central Única dos Trabalhadores (CUT), no Movimento dos Trabalhadores Rurais Sem Terra 
(MST), no Movimento dos Trabalhadores Desempregados (MTD), e no Fórum Nacional da Educação do Campo (FONEC).

As cinco teses são colocadas na perspectiva da crítica marxista ${ }^{6}$, pois devem ser consideradas as seguintes questóes:

- Não existe um modelo de educação a partir do qual seria medida a educação existente ou que seria preparada a educação do futuro. Existe o que está posto, a partir do qual se constrói o la contra. Não é um plano alternativo de educação, nem tampouco a educação de um plano alternativo de sociedade, igualmente inexistente. Não é uma dedução a partir de um suposto modelo de sociedade, mas, sim da expressão geral do movimento real;

- A crítica tem que ser materialista. Não tem sentindo a crítica a partir de possíveis ideais educativos ou de uma determinada ideia definida de homem e das suas necessidades. Ao contrário, a crítica deve ser construída sobre a base de que não existem nem homem abstrato, nem homem em geral, mas sim o homem que vive dentro de uma dada sociedade e em um dado momento histórico, que está determinado pela configuração social e pelo desenvolvimento histórico concreto, dos quais emergem necessidades, não limitadas somente ao homem, mas, sim necessidades históricas e sociais, entre as quais estão as necessidades no aspecto educativo;

- A crítica não deve perder em momento algum a visão de totalidade histórica e social. Se um dos objetivos confessos de toda educaçáo é formar a consciência do homem, a crítica da educação deve abarcar todas as vias através das quais se produz e reproduz a consciência social e individual;

- A crítica deve mostrar a relação entre valores educativos e as condições das bases materiais que as sustentam e deve contribuir para a sua destruiçấo. A crítica destes valores educativos é, por sua vez, a crítica de todo o reformismo pedagógico que consiste em modificar as consciências através da ação educativa, da inculcação, da ação pedagógica;

- A análise econômica terá muito a dizer, situando a educação dentro do processo de produção e reproduçáo do capital e do valor, explicitando qual o papel que ela joga neste processo;

- Há que compreender a valoração crítica da educação realmente existente, das ideias dominantes e outros aspectos da vida social que contribuem para os sucessos ou fracassos no campo da educação, que significa buscar a solução para antíteses reais nas tendências reais existentes (ENGUITA, 1985). 
Nesse sentido, portanto, são apresentadas as cinco teses sobre Educação, Consciência de Classe e Revolução, com o que lhes é subjacente.

A Primeira Tese diz respeito à funçáo social da escola, que é elevar a capacidade teórica dos estudantes, o que passa pelo desenvolvimento da capacidade científica, a atitude científica, a valorização da aquisição pelo estudante dos conhecimentos científicos, artísticos e filosóficos em sua forma mais desenvolvida, o que implica no desenvolvimento de funçóes psicológicas superiores. Ela está em contra ponto com a função atribuída à escola pela burguesia que é moldar subjetividades humanas para facilitar as condiçóes gerais do processo de acumulação de riqueza.

Esta função é historicamente constituída e, a escola ensina, mesmo quando parece não ensinar. A esta perspectiva de escola se opóe ao projeto da classe trabalhadora que atribui à escola outra função social: a de elevar as funçóes psicológicas, a capacidade teórica e a atitude científica dos estudantes. Considerando, portanto, que:

Todas as funçôes [...] aparecem duas vezes: primeiro em nível social, e mais tarde em nível individual, primeiro entre pessoas (interpsicológico), e depois no interior da própria criança (intrapsicológica). Pode-se aplicar isso igualmente à atenção voluntária, à memória lógica e à formação de conceitos. Todas as funçôes psicológicas se originam como relaçôes entre seres humanos. (VIGOTSKY, 1996, p. 75, grifo nosso).

Essas funções não se dão fora da aprendizagem ${ }^{8}$, tanto de processos psíquicos quanto do domínio de instrumentos e ferramentas de pensamento e de pesquisas desenvolvidas ao longo da história da humanidade ${ }^{9}$ para se conhecer o real concreto e superar o mundo da pseudoconcreticidade ${ }^{10}$, ou seja, das representações do real.

Podemos, pois, dizer que a natureza humana não é dada ao homem, mas é por ele produzida sobre a base da natureza biofísica. Consequentemente, o trabalho educativo é o ato de produzir, direta e intencionalmente, em cada indivíduo singular, a humanidade que é produzida histórica e coletivamente pelo conjunto dos homens. (SAVIANI, 2003, p. 13). 
A escola é o principal local ${ }^{11}$ onde esta função social, cara a formação da classe trabalhadora, deve ser materializada. Ela é, portanto, o local de universalização da cultura enquanto possibilidade concretamente existente. Segundo Leontiev (2001), a meta é a concretizaçáo, na vida de todos os seres humanos, das máximas possibilidades de desenvolvimento, pois os seres humanos não nascem humanos, humanizam-se pela cultura.

A possibilidade existe, mas sua concretização dependerá de nossas ações nessa direção. Isso implica partir da crítica marxista à escola capitalista ${ }^{12}$.

Por sua vez, o êxito dessas ações dependerá do grau de compreensão que teremos dos processos sociais em curso e da capacidade de atuação estratégica e tática na luta de classes ${ }^{13} \mathrm{em}$ geral, e em especial nas lutas específicas no campo da educação que passam pela defesa da escola pública, laica, gratuita e socialmente referenciada.

Pela defesa do ato de ensinar (MARTINS; ARCE, 2007), passa-se pelo combate ao projeto de mundialização da educação (MELO, 2004), combate a contra reforma na educação superior (LIMA, 2007), a nova pedagogia da hegemonia (NEVES, 2005) e pela crítica ao construtivismo (DUARTE, 1993, 1996, 1998a, 1998b, 2003, 2004a, 2004b), ao escolanovismo e ao relativismo epistemológico (SANTOS, 2011) que impregnam as pedagogias do capital, os cursos de formação de professores, a escola e a universidade.

A Segunda Tese diz respeito aos trabalhadores em educaçáo, sua formação, remuneração, assistência, saúde, previdência. Em especial o professor e sua formaçáo que deve permitir o desenvolvimento de uma consistente base teórica e de um conhecimento crítico para combater as pedagogias do capital e o projeto mundial de educação que são hegemonicamente sustentados nos cursos de pedagogia e nas licenciaturas em geral.

Professores com consistente base teórica, capazes de garantir aos estudantes a transmissão do legado da humanidade, que são dignamente remunerados, com um piso salarial nacional que lhe garanta o exercício competente da funçáo de professor, com condiçóes de trabalha ${ }^{14}$. Professores com oportunidades e com condiçóes de formaçáo continuada a altura do desafio da escola pública, em programas de Pós-Graduaçáo presenciais, com bolsa de estudos para todos, em universidades públicas. Professores que tenham perspectiva de previdência, com aposentadoria pelo sistema de solidariedade de classe, que tenha assistência e saúde. 
Professores articulados politicamente com suas organizaçóes de classe autônoma, independentes e com capacidade de lutar, a partir de onde efetivará a mobilização, organização com vista ao atendimento de reivindicações da comunidade escolar. Professores, militantes culturais que atuam em uma escola capitalista, sendo capaz de lhe tecer a crítica e propondo outra organização do trabalho pedagógico na sala de aula, na escola, na comunidade, no movimento dentro de outra lógica que não a lógica do capital. Professores que ingressem na carreira por concurso público, e seja contratado pelo regime jurídico único que garantam-lhes direitos trabalhistas. Isso implica ser contra o Exame Nacional de Ingresso na Carreira Docente, contra a matriz construtivista de exame que está sendo proposta e que ignora os fundamentos clássicos da teoria educacional. Implica, também, em lutar para que o Sistema Nacional Público de Formação de Professores do Ensino Básico fique sob a responsabilidade da Coordenaçáo de Aperfeiçoamento de Pessoal em Nível Superior (CAPES), e para que a área de educação tenha representatividade na CAPES, elegida entre seus pares, em processos democráticos, transparentes e participativos.

A Terceira tese é que essa escola sustente um programa de vida, que tenha o trabalho socialmente útil como princípio educativo - que se desenvolva com base em um currículo de tempo integral, de referência nacional, que permita acesso aos conhecimentos científicos e tecnológicos, às humanidades e arte, à educação física, que tem no esporte, no jogo, na dança, nas lutas, nas ginásticas a expressão de suas formas mais elaboradas.

Uma escola que permita aos estudantes desenvolverem a capacidade de constatar, sistematizar, compreender, explicar e atuar na vida concreta na linha da revolução permanente. Escola que admita as diferentes formas do trabalho socialmente útil - auto-serviço, oficinas, trabalho produtivo, e outros (PISTRAK, 2009). Escola que se inicia na educação infantil e culmina na pósgraduação, permitindo o ingresso amplo geral e irrestrito, que seja sem barreiras de nenhuma ordem, e que garanta, portanto, o ingresso, a permanência e a finalização com êxito e qualidade, garantindo a assistência necessária para tal. Isso significa opor-se ao esvaziamento da escola e de seus conteúdos, lutar contra as barreiras que obstaculizam o ingresso, a permanência e o êxito escolar, pela assistência estudantil, e por um programa que seja realmente um programa de vida.

A Quarta tese defende que o financiamento (DAVIES, 2004) dessa escola não esteja atrelado ao Produto Interno Bruto (PIB) e às Leis de Responsabilidade 
Fiscal, mas que ela seja financiada de acordo com o cálculo resultante do custo do aluno, com base no padrão unitário nacional de qualidade, definidos pelos trabalhadores em educação e seus organismos de classe e que se aplique à legislação vigente sobre financiamento. Segundo Davies (2004),

O primeiro e principal desafio não é fixar, no papel, que os governos apliquem 10\% do PIB (Produto Interno Bruto) em manutenção e desenvolvimento do ensino (MDE), [...] mas garantir que pelo menos cumpram as exigências constitucionais de aplicação do percentual mínimo dos impostos estipulado nas Constituições Federal (no caso do Governo Federal), Estaduais (no caso de governos estaduais) e Leis Orgânicas (no caso de prefeituras).

É dar o combate contra os desvios de verbas da educaçáo. DAVIES (2004) destaca que alguns dos principais desafios do financiamento da educaçáo pública no Brasil são:

[...] o descumprimento da vinculaçáo constitucional de impostos para a manutenção e desenvolvimento do ensino, as perdas astronômicas provocadas pela inflação dos recursos vinculados, o desvio de recursos da educação, a corrupção generalizada, a sonegação fiscal, a fiscalização deficiente por parte dos Tribunais de Contas, a inexistência de controle social, a isençáo fiscal para escolas privadas e filantrópicas,os subsídios às escolas privadas, o clientelismo e o peso da burocracia. [...] estes problemas náo devem ser vistos como se fossem separados uns dos outros, mas fazendo parte de uma mesma lógica, que é a da privatizaçấo do Estado por dentro e por fora, uma característica estrutural dos Estados capitalistas que se acentuou na fase atual orientada pelo neoliberalismo. (DAVIES, 2004, grifo do autor).

A Quinta tese, a autonomia da gestáo e administraçáo escolar, do Estado, de governo, de governantes, de seus programas, das igrejas e suas crenças, sejam elas católica, protestantes, evangélicas, pentecostais, espíritas e de raízes africanas. Autonomia em relação à partidos e sindicatos, à Conselhos Profissionais que infernizam os trabalhadores da educaçâo, como podemos 
constatar pelos fatos concretos da luta do Movimento Nacional Contra a Regulamentação da Profissão (MNCR) contra o Conselho Federal de Educação Física (CREFE) e a luta do Movimento dos Estudantes de Educação Física pela formação unificada, pela não divisão na formação que tem o intuito de desqualificar o trabalhador em sua formação acadêmica.

Isso significa, também, a luta contra as pedagogias do capital e enfrentar a pedagogia burguesa no interior da escola, conforme demonstra Saviani (2008). Lutar contra a nova governança mundial que pretende construir consensos e edificar uma escola sem que o estado assuma sua responsabilidade no financiamento, contra o controle ideológico da escola por parte do Estado, que nada mais é do que a organização do poder da burguesia.

Cabe aos trabalhadores educar o Estado e não o inverso, ou seja, Estado educar a classe trabalhadora. Devem lutar contra ideia da "autonomia financeira", que coloca o sistema educacional na lógica do mercado, dos parceiros, dos patrocinadores, dos financiamentos externos, da privatização, do filantropismo e dos amigos da escola. Tem que defender os princípios socialistas da gestão onde trabalhadores livremente associados, com base em necessidades humanas desenvolvem seu trabalho, para superar a exploração de classe. Uma coisa é determinar, por meio de uma lei geral, os recursos, e outra, completamente diferente, é nomear o Estado o educador do povo. Contrariamente, o que se há de fazer é subtrair a escola a toda e qualquer influência por parte do governo, pois, segundo Marx (1975), é o Estado que necessita receber do Povo uma severa Educação.

\section{Articulando as teses com as lutas pelas reinvindicações}

Essas teses específicas da educação estão inscritas dentro do conjunto de reivindicaçôes particulares da classe trabalhadora brasileira, colocadas nesse momento histórico. Os trabalhadores brasileiros travam uma forte luta de classes que se expressa em três âmbitos: econômico, político e ideológico.

No âmbito econômico, vimos travada a luta pelo salário mínimo, e também a austeridade econômica expressa no corte de 50 bilhóes que incidirá nos serviços públicos. Estamos presenciando a luta dos grevistas da construção civil, a greve dos servidores públicos e dos serviços terceirizados.

Os cortes no orçamento da união de mais de 50 bilhōes, com repercussōes nos estados, é possível observar a mobilização dos estudantes contra tais cortes 
na educação. Quanto à fixação do salário mínimo, em torno de $\mathrm{R} \$ 545,00$, presenciamos também uma disputa que repercutirá na capacidade de consumo da classe trabalhadora. O salário mínimo estabelecido em 2011 rompe com a política de valorizaçáo ${ }^{15}$, incidindo na consciência da classe dos trabalhadores. Essa incidência dependerá sim do trabalho por dentro dos sindicatos e dos movimentos de luta social da classe trabalhadora. A Câmara dos Deputados e o Senado aprovaram a proposta do governo Dilma de $\mathrm{R} \$ 545,00$ para o salário mínimo, a partir de $1^{\circ}$ de março de 2011 , recusando com isso conceder um aumento real, como defendeu a Central Única dos Trabalhadores (CUT), em torno de $\mathrm{R} \$ 580,00$, o que significa a interrupção da política de valorização do salário mínimo.

Como vivemos em um país capitalista, inserido na economia mundial em crise profunda, cada vez mais acentuada a partir de 2008, onde não são os trabalhadores que controlam os meios de produção e a economia, mas, sim, os capitalistas e, em alguns casos, o Estado. A lógica "PIB+inflação", base do acordo realizado com as Centrais Sindicais, durante o Governo de Luiz Inácio Lula da Silva (2003-2010), fragiliza as posições da classe trabalhadora. Em 2010, o PIB cresceu 7,5\% e mesmo assim não ocorreu uma valorizaçáo do salário mínimo. Em 2011, a previsão de crescimento do PIB é de 5\%, o que indica que não teremos novamente a valorização do salário mínimo. Quanto a Participação em Lucros e Resultados (PLR), organizar a economia no modo capital é assegurar os lucros dos que detém os meios de produção, em detrimento da progressiva redistribuição de renda entre os trabalhadores. Isso vem sendo assegurado pela "governança corporativa", que busca tornar os trabalhadores co-responsáveis pelos desempenhos das empresas e gestóes de governo. Com isso, não se desenvolve uma verdadeira política de valorização do salário mínimo, que implicaria numa progressiva redistribuição de renda em favor dos assalariados.

Portanto, entre as bandeiras de luta da classe trabalhadora está o cumprimento da Constituiçáo da República Federativa do Brasil de 1988, no que diz respeito aos direitos dos trabalhadores. Quanto ao salário mínimo, levando em conta a Constituição, seria necessário implantá-lo segundo os cálculos do Departamento Intersindical de Estatísticas e Estudos Sócioeconômicos (DIEESE), que estaria atualmente por volta de R 2.280,00.

Outro ponto a destacar das lutas dos trabalhadores organizados nas Centrais Sindicais e nos Movimentos de Luta Social da classe trabalhadora é a retirada das tropas brasileiras do Haiti. A visita recente do Sindicalista Fignolé, 
da Central Sindical Haitiana (CATH), em audiência na Secretaria Nacional dos Direitos Humanos, demonstrou a situação em que vive a classe trabalhadora haitiana após sete anos de ocupação das tropas da Organização da Naçôes Unidas (ONU). O que temos que reivindicar no conjunto é a retirada das tropas e sua substituição por médicos, engenheiros, professores entre outros profissionais.

Podemos identificar, pelos exemplos mencionados, que as lutas da classe trabalhadora brasileira, neste momento histórico, inserem-se em lutas de alcance internacional como é a revolução proletária em curso na Tunísia. Os jovens em situação precária e desempregados, os trabalhadores, os camponeses e outras camadas da populaçáo puseram-se em movimento em torno da palavra de ordem: "AGUA E PÃO, BEM ALI NÃO!".

O que esta ocorrendo é a reação dos trabalhadores às ditaduras, monarquias, mas fundamentalmente à acordos internacionais de ajustes estruturais, firmados entre países imperialistas e governantes para manter a divisão internacional do trabalho, fontes energéticas e taxas de lucro. Na Tunísia, os trabalhadores procuram reapropriar-se da sua organização histórica, a União Geral dos Trabalhadores da Tunísia (UGTT), principal vetor da mobilização massiva, e constituir seus comitês de defesa da revolução. A coluna vertebral desse processo são os jovens e os sindicalistas. O país demonstrou pelos fatos que a classe trabalhadora, apoiando-se na sua organização histórica, tem condiçôes de agrupar a nação contra o imperialismo e seus vassalos. Constata-se uma revolução de trabalhadores atacando um regime sujeito ao imperialismo, sistema baseado na propriedade privada dos meios de produção.

Abre-se uma nova etapa da situação mundial. Para o imperialismo a solução é a guerra, juntam-se, portanto, imperialistas norte-americanos e europeus por pretextos "humanitários". A intervençáo militar na Líbia, ameaçada pelos Estados Unidos e com o apoio tímido da França, visa à revolução proletária na Tunísia e o levante revolucionário no Egito. O Movimento da revolução proletária internacional está se caracterizando na defesa das organizaçóes da classe operária, necessária ao combate, bem como, à organizaçăo das massas no seu próprio terreno, através dos comitês que se erguem contra o imperialismo.

O combate a ser dado é pela unidade e independência de classe. Isso significa dizer não a intervenção militar imperialista e a qualquer ingerência, e dizer sim a garantia aos povos em luta o direito a sua autodeterminação a solidariedade operária. 
A respeito do conflito, confronto de classes e a consciência dos trabalhadores, Lênin (1978, p. 58 ) demonstra com dados concretos que:

A consciência das massas operárias não pode ser uma verdadeira consciência de classe se os operários não aprenderem, com base em fatos e acontecimentos políticos concretos e, além disso, necessariamente de atualidade, a observar cada uma das outras classes sociais em todas as manifestaçôes de sua vida intelectual, moral e política; se não aprenderem a aplicar na prática a análise materialista e a apreciaçáo materialista de todos os aspectos da atividade e da vida de todas as classes, camadas e grupos da população.

Essas teses circunstanciadas, portanto, a partir de fatos concretos e reivindicaçôes dos trabalhadores na realidade brasileira, necessitam de explicaçóes científicas e, assim o faremos, a partir da consideração dos conceitos clássicos sobre educação, consciência de classe e estratégia revolucionária.

\section{As explicações necessárias}

O fio condutor para explicar a articulação das teses aqui apresentadas com a luta mais geral da classe trabalhadora é a formação econômica e sua revolução, ou seja, no modo de vida, sua superação e os indicadores de que a humanidade superou uma velha fase para ingressar em uma nova formação econômica e, correspondendo a ela, uma nova superestrutura jurídica e ideológica.

Para tratar de formaçôes econômicas, base material da existência humana sob a qual se ergue a superestrutura ${ }^{16}$, utilizarei a obra de Engels (2001), sobre A Origem da Familia, da Propriedade Privada e do Estado, escrita em 1884, portanto, após a morte de Marx. No prefácio da primeira edição, datada de 1884, Engels deixa claro que as páginas do livro, de certo modo, seria a execução de um testamento.

Sobre a obra, Marx dispunha-se a expor os resultados das investigaçóes do norte-americano Lewis Henry Morgan, etnógrafo e historiador da sociedade primitiva, a partir de sua análise materialista da história, que viveu de 1818 a 1881. É a partir de excertos detalhados que Marx retirou da obra de Morgan, que investigou durante 40 anos para dominar inteiramente o assunto, que Engels 
(2001) sistematiza uma brilhante contribuição para entendermos o que, afinal de contas, levou a humanidade a configurar a família, constituir classes sociais antagônicas e levantar o Estado da forma como o conhecemos na atualidade, a saber, a família monogâmica, a classe burguesa, a classe trabalhadora e o Estado Burguês.

Conforme a concepção materialista, o fator decisivo na história é, em última instância, a produção e a reprodução da vida imediata, produção e reprodução que são de dois tipos: a produção dos meios de existência alimentos, habitação e instrumentos necessários para tudo isso; e, de outro lado, a produção do homem mesmo, a continuação da espécie, que não se resumo a um fenômeno biológico, mas sim sócio-histórico. Engels (2001, p. 7) nos diz literalmente no prefácio à primeira edição do livro:

A ordem social em que vivem os homens de determinada época ou determinado país está condicionada por duas espécies de produção: pelo grau de desenvolvimento do trabalho, de um lado, e da família de outro. Quanto menos desenvolvido é o trabalho, mais restrita é a quantidade de seus produtos e, por conseqüência, a riqueza da sociedade; com tanto maior forca se manifesta a influencia dominante dos laços de parentesco sobre o regime social. Conduto, nesta estrutura de sociedade, baseada nos laços de parentescos, a produtividade do trabalho aumenta sem cessar, e, com ela, desenvolvem-se a propriedade privada e as trocas, diferenças de riqueza, a possibilidade de empregar forca de trabalho alheia, e com isso a base dos antagonismos de classe: os novos elementos sociais, que no transcurso de geraçôes, procuram adaptar a velha estrutura da sociedade à novas condiçóes, até que, por fim a incompatibilidade entre esta e aquela leva a uma revolução completa.

Ao tratar da pré-história da humanidade e suas três principais épocas estado selvagem, barbárie e civilização, Morgan estudou principalmente as fases inferior, média e superior dos estados selvagens e da barbárie, e a passagem da barbárie para a civilizaçáo a partir dos progressos obtidos na produção dos meios de existência. É critério conclusivo para a delimitação dos períodos a ampliação das fontes de existência. É Marx que deixa o maior legado para entendermos 
a formação econômica capitalista, devido aos seus estudos sobre formações econômicas pré-capitalistas.

Segundo Engels (2001), a partir dos estudos de Marx sobre Morgan, podemos concluir que o Estado Selvagem é o período em que predomina a apropriação dos produtos da natureza, prontos para serem utilizados; as produçôes artificiais dos homens são, sobretudo, destinadas a facilitar essa apropriação. A barbárie é o período em que aparece a criação de gado e a agricultura e se aprende a incrementar a produção da natureza por meio do trabalho humano. A civilização seria o período em que o homem continua aprendendo a elaborar os produtos naturais, ou seja, período da indústria propriamente dita e da arte.

A cada um desses períodos correspondeu à constituição de família, de propriedade e de Estado. Sob essa base se estabeleceram as formas de educar, ou seja, de transmitir de uma geraçáo a outra o acervo cultural acumulado historicamente nas relaçóes sociais de produção.

Da domesticação dos animais à criação do gado, foram abertos mananciais de riqueza criando relaçóes completamente novas, e do que era comum passouse a desenvolver a propriedade privada de rebanhos, de produtos artísticos, de utensílios de metal, objetos de luxo, da terra, até o gado humano: os escravos. Nessas relaçóes de uso estabelecem-se relaçóes de troca e, assim, constituem o poder dos que detém o poder de estabelecer os códigos e normas que se complexificam ao longo da história até tornarem-se direitos constitucionais. E é lá que está assegurada à propriedade ilimitada da terra e dos meios de produção da vida, nas constituições das naçôes.

No umbral da civilização vamos encontrar o período inferior da barbárie, onde a divisão social do trabalho se dá com os homens produzindo apenas para as suas necessidades diretas. As trocas reduziam-se ao caos isolado e tinham por objeto os excedentes obtidos por acaso. $\mathrm{Na}$ fase média da barbárie já nos defrontamos com formas de propriedade, com uma produção de excedente regular sobre o consumo, e com uma divisão de trabalho relacionada com as tribos mais atrasadas e seus graus de produçáo, que implicavam em certa regularidade de trocas. Na fase superior da barbárie, vamos encontrar, segundo Engels (2001), uma divisão ainda maior de trabalho, entre a agricultura e o artesanato - objetos fabricados para a troca e a elevação da troca entre produtores individuais e disso resultaria a elevaçâo de necessidade vital para a sociedade. 
A civilização consolida e aumenta todas as divisóes do trabalho já existentes, acentuando o contraste entre a cidade e o campo e acrescenta uma terceira divisão do trabalho, criando uma classe que não se ocupa da produção: os comerciantes que sem fazer parte direta da produção conquistam a direçấo geral da mesma e avassalam economicamente os produtores, intermediário entre os dois produtores e que explora a ambos. Com ela veio o dinheiro metal, foi o meio encontrado para que o não produtor dominasse o produto e sua produçẫo. Encontrou-se assim a mercadoria que encerra em estado latente todas as demais.

Criou-se o dinheiro frente ao qual todos deveriam prosternar-se. Ficou provado de maneira prática que essa era a genuína encarnação da riqueza, e sob essa base criou-se a jurisprudência, criaram-se leis sob a forma de direito consuetudinário, não sujeito a outra compulsão se não a economia. Assim, ao lado da riqueza em mercadorias, escravos, dinheiro, consolida-se a riqueza em terra - a propriedade privada da terra - que passa a ser transmitida por herança e a partir da qual se cria a hipoteca.

Surge, dessa forma, uma sociedade que por força das condiçóes econômicas gerais da existência divide-se em homens livres e escravos, em exploradores e ricos, e explorados e pobres, uma sociedade onde os antagonismos não podiam mais ser conciliados como ainda tinham que ser levados aos seus limites extremos. Uma sociedade desse gênero não subsiste senão em meio a uma luta aberta $\mathrm{e}$ incessante das classes entre si, ou sob o domínio de um terceiro poder que, situado aparentemente sob as classes em luta, suprimisse os conflitos abertos e só permitisse a luta de classes no campo econômico, numa forma dita legal.

Ergue-se, portanto, o Estado, que não é um poder que se impôs à sociedade de fora para dentro, tampouco é "a realidade da ideia moral", e nem "a imagem e realidade da razáo". É sim um produto da sociedade quando chega a um determinado grau de desenvolvimento. Portanto, o Estado é reconhecido pelos seus traços de agrupar seus súditos de acordo com uma divisão territorial, manter uma força pública, recolher imposto e emitir títulos de dívida pública quando os impostos são insuficientes. Desse modo, como o Estado nasceu da necessidade de conter antagonismos de classes, e como, ao mesmo tempo, nasceu em meio ao conflito delas, é, por regra, segundo Engels (2001), o Estado da classe mais poderosa, da classe economicamente dominante, classe que, por intermédio dele, se converte em classe politicamente dominante e adquire novos meios para a repressão da classe dominada. É assim que o Estado antigo é o Estado dos senhores de escravos, o estado feudal, o órgão de que se valeu a nobreza para 
subjugar servos e camponeses dependentes, e o Estado Moderno representativo é o instrumento de que se serve o capital para explorar o trabalho assalariado.

As classes em oposição tornam-se conscientes de si na luta, reconhecendose, portanto, enquanto classe para si. De classe em si, para classe para si decorre um tempo histórico de lutas, confrontos, conflitos e antagonismos que não serão concluídos enquanto prevalecer a atual forma de civilização humana, baseada na subsunção do trabalho ao capital. Assim, o ser humano genérico, não nasceu ser humano, tornou-se ser humano na luta dos contrários, na negação da negação, nos saltos quantitativos e qualitativos em dadas relaçóes de produção da vida.

A cada um desses períodos corresponderam possibilidades concretas de formação humana, com base nas condiçóes objetivas da vida, e em cada um desses estados correspondeu um grau de consciência da classe, que surge e se consolida em processos sócio-históricos que se dão em dois planos: nas relaçôes interpessoais, e em relaçóes e processos intrapessoais, intrapsíquicos.

Portanto, é sob uma base concreta, material da existência humana, que se consolida as relaçóes sociais, entre as quais, relaçôes educacionais, que permitirão a reprodução, ou não, de determinadas condiçôes objetivas da existência humana. Os rumos da educação estão na dependência da luta de classes. Quanto mais estiverem ao acaso, mais agem as leis que transformam, por exemplo, a escola em aparelho ideológico do Estado. Quanto mais estiverem ao acaso, sem que se entendam as leis que regem a escola capitalista, mais se considera natural a sua forma capital.

Quanto mais estiverem ao acaso os produtos e os produtores, tanto mais agem o que são as leis internas, as leis próprias, imanentes a tais processos. Desconsiderar, portanto, as leis próprias e inerentes de uma atividade social, de uma série de processos sociais, mais os processos escapam do controle consciente, mais parece ser uma necessidade "natural". Isso aplicado às taxas de lucro como sendo uma necessidade imanente do capital, explica o motivo pelo qual, cada vez mais, o capital recorre a formas mais violentas para mantê-las a custa do sacrifício da própria força de trabalho.

Segundo Engels (2001, p. 180-181),

As leis econômicas da produção monopolista modificamse de acordo com os diversos graus de desenvolvimento todo o período da civilizaçáo, em geral, está regido por elas. Até hoje o produto domina o produtor, até hoje 
toda a produção social é regulada, não segundo um plano elaborado coletivamente, mas por leis cegas que atuam com a forca dos elementos, em última instância nas tempestades dos períodos de crise comercial. Desde que a civilização se baseia na exploração de uma classe por outra, todo o seu desenvolvimento se opera numa constante contradição. Cada progresso na produção é ao mesmo tempo um retrocesso na condição da classe oprimida, isto é, da imensa maioria. Cada benefício para uns é necessariamente um prejuízo para os outros. Cada grau de emancipação conseguido para uma classe é um novo elemento de opressão para a outra. Quanto mais progride a civilizaçáo mais se vê obrigada a encobrir os males que traz necessariamente consigo, ocultando-os com o manto da caridade [...] elabora-se uma hipocrisia convencional de que a classe opressora explora a classe oprimida e unicamente para o próprio benefício dela.

Conclui Engels (2001), que o tempo que transcorreu desde o início da civilização não passa de uma fração ínfima da existência passada da humanidade, das épocas vindouras. A dissolução da sociedade ergue-se diante de nós, é o fim de um período histórico, cuja única meta tem sido propriedade da riqueza, pois esse período encerra os elementos de sua própria ruína.

\section{As estratégias da classe trabalhadora}

A partir dessa base teórica, vamos buscar na história o que permite reconhecer a estratégia revolucionária em um período histórico em que se instala e consolida o Estado burguês, o Estado ocupado pela forças dominantes, forças econômicas, políticas e ideológicas do capital.

Carlos Montano e Maria Lúcia Duriguetto (2011), em publicação na Coleção Biblioteca Básica do Serviço Social, tratam da temática Estado, Classe e Movimento Social, e nos apresentam conceitos fundamentais sobre o Estado Moderno e a sociedade civil nos clássicos da teoria política. Ao tratarem sobre classe social, consciência de classe e lutas de classe, partem do modo de produção capitalista e apresentam o capital e o trabalho, a dimensão ontológica e histórica.

Os elementos estruturais das principais classes do modo de produção capitalista são categorias econômicas que simbolizam relaçóes e interesses de 
classe (MONTANO; DURIGUETTO, 2011). São tendências do capitalismo: a separação do trabalho em relação aos meios de produção; a concentração e centralização do capital; a transformação do trabalho em trabalho assalariado; e a transformação dos meios de produção em capital. A partir daí caracterizamse as classes, que são grupos de homem que se diferenciam entre si pelo lugar que ocupam em um sistema de produção social historicamente determinado.

Sobre a consciência de classe, destacam os autores, ao superar a mera percepção imediata e parcial da realidade e a alienada vida cotidiana sob a hegemonia do capital, desmistificando-se a ideologia hegemônica e desenvolvese uma consciência humano-genérica, em que se dá o transito de uma consciência em-si para uma consciência para-si. Desenvolve-se, assim, uma consciência de classe (MONTANO; DURIGUETTO, 2011). A luta de classes tem dois objetivos: sindical e revolucionário.

Os autores diferenciam a luta de classes e as lutas sociais, que são expressões em consequência do que é estruturante e não pode ser subsumido, que é a contradição capital-trabalho, em suas manifestaçóes (refraçôes da "questáo social"). Concluem os autores, que o sujeito para transformar o modo de produção é a classe trabalhadora (MONTANO; DURIGUETTO, 2011).

Ao tratar sobre o Estado Montano e Durigetto (2011) iniciam expondo o conceito de "Estado do Bem Estar" e as lutas trabalhistas no regime de acumulaçáo fordista/keynesiano à (contra) reforma do Estado no regime de acumulação do grande capital. Eles concluem esse capítulo abordando a questão da diminuição do poder do trabalhador e o aumento do poder do capital.

Por fim, os autores discutem os Movimentos Sociais, sujeitos, projetos e espaços das lutas sociais, tratando dos Movimentos de Classe (Sindical) e Movimento de Libertaçáo Nacional até os Novos Movimentos Sociais. Concluem que as lutas e os movimentos sociais dos trabalhadores estiveram, ao longo da história, circunscritas a reformas ou contra-reformas, ou a revoluçóes ou contra-revoluçôes (MONTANO; DURIGUETTO, 2011).

Para apreender as mediaçôes entre essas duas estratégias - a reformista, cujo horizonte de luta é a conquista de direitos, e a revolucionária, cujo horizonte é a transformaçáo radical do modo de produçáo capitalista, Montano e Duriguetto (2011) ressaltam que a luta por direitos, justiça e equidade só adquire caráter emancipatório se estiver em consonância, em sintonia, na luta por um projeto de superaçấo da ordem social vigente. Se num primeiro momento a 
revolução volta-se para a resolução de problemas básicos, como a eliminação social da fome e do analfabetismo, e como a criação das condiçóes materiais básicas que assegurem a vida, precisamos não perder de vista que essa não é a meta da revolução. A sua meta é superar um dado modo de produção da vida, que é o modo do capital organizar a produção dos bens materiais e imateriais.

O que constatamos é que o capital, a nível mundial, investe para destruir as forças produtivas, a classe trabalhadora e suas organizaçóes. $\mathrm{O}$ grau de desenvolvimento da classe para si pode ser verificado pelos fatos, no enfrentamento da lógica do capital. As derrotas, os retrocessos, as perdas são resultantes dessa luta de contrários inconciliáveis, a saber, a classe burguesa e seu projeto de manter a hegemonia do capital, a classe trabalhadora e seu projeto socialista. Segundo Trotsky (1938, p. 8),

Sem vitória da revoluçáo socialista no próximo período histórico, toda a civilização humana está ameaçada de ser conduzida a uma catástrofe. Tudo depende do proletariado, ou seja, antes de mais nada, de sua vanguarda revolucionária. A crise histórica da humanidade reduz-se à crise da direção revolucionária [...]. A tarefa estratégica do próximo período - período pré-revolucionário de agitação, propaganda e organização - consiste em superar a contradição entre a maturidade das condiçôes objetivas da revolução e a imaturidade do proletariado e de sua vanguarda (confusão e desencorajamento da velha geraçāo falta de experiência da nova). É necessário ajudar as massas, no processo de suas lutas cotidianas a encontrar a ponte entre suas reivindicaçóes atuais e o programa da revolução socialista. "Esta ponte deve consistir em um sistema de reivindicaçóes transitórias que parta das atuais condiçôes e consciência de largas camadas da classe operária e conduza, invariavelmente, a uma só e mesma conclusấo: a conquista do poder pelo proletariado".

Quanto às dificuldades que enfrentamos, elas decorrem de muitos fatores a serem profundamente estudados, mas aqui gostaria de destacar que essas dificuldades decorrem em função da separação que se faz entre premissas teóricas e programáticas. Separação entre condiçôes objetivas e subjetivas para enfrentarmos os processos violentos que se avizinham. As relaçôes políticas 
que estão estabelecidas estão forjando uma intersubjetividade e um sistema de valores da classe trabalhadora que a mantém refém, alienada, subsumida ao capital e sua lógica.

E isso decorre, provavelmente, das características que vem assumindo o marxismo ocidental ${ }^{17}$. A esse respeito Perry Anderson, em livro organizado por Pucci (1995), deixa evidente que o marxismo ocidental apresenta entre suas principais características o seguinte:

[...] a) o divórcio estrutural do marxismo com a prática política, da teoria com a práxis; b) o silêncio premeditado do marxismo ocidental em áreas fundamentais para as tradições clássicas do materialismo histórico: as leis econômicas do funcionamento do capitalismo como um modo de produção, a análise da máquina política do estado burguês, a estratégia da luta de classes necessária para derrubá-la; c) deslocamento do eixo gravitacional do marxismo europeu no sentido da filosofia, de estudos da superestrutura, com sua conseqüente academização. (ANDERSON, 1989 apud PUCCI, 1995, p. 13).

Para Anderson (1989) ajustar as contas com essa tradição, isto é, conhecêla e romper com ela, é assim um dos pré-requisitos para uma renovação da teoria marxista hoje

\section{O que fazer? Não separar pressupostos teóricos e programáticos}

$\mathrm{Na}$ linha de não separar pressupostos teóricos de programáticos, para concluir, menciono três documentos históricos escritos em situaçôes revolucionárias que nos permitem reconhecer o que fazer estrategicamente nesse momento em que as principais reivindicações referentes à Educação dizem respeito à defesa da função social da escola, seu financiamento, sua gestão democrática, seu currículo articulado a uma concepção de formação humana emancipada e de valorização do magistério. Esses documentos expressam historicamente a tensão e as disputas pelos rumos da Educação no país. Abre-se um novo período visível no confronto entre as classes nos países onde a classe trabalhadora luta contra o imperialismo. Os documentos que nos permitem 
lições históricas são os seguintes:

- O Manifesto do Partido Comunista, elaborado por Marx e Engels (2008) em 1848, no qual destacamos as duas conclusóes iniciais dos autores sobre o espectro que ronda a Europa, o espectro do comunismo, e a conclusão sobre a união dos proletários do mundo.

A respeito do que concluem Marx e Engels (2008), que o comunismo já é reconhecido como força, e que é tempo dos comunistas exporem, diante do mundo inteiro, seu modo de ver, seus fins e suas tendências, opondo um manifesto as lendas sobre o espectro do comunismo. Do Manifesto apreendemos que a história de toda sociedade existente até hoje tem sido a história das lutas de classes, sem o que não é possível compreender a consciência de classe na atualidade.

Marx e Engels (2008) destacam que as conclusôes teóricas dos comunistas não se baseiam em ideias ou princípios inventados, mas que esses princípios são a expressão geral das condições reais de uma luta de classes existente, de um movimento histórico que se desenvolve diante dos nossos olhos. Destacam que a revolução comunista exige o rompimento mais radical com as ideias tradicionais, pois essa revolução é o rompimento com as relaçóes tradicionais.

Com base nessas premissas, os autores apresentam teses cujo teor demonstra a impossibilidade de uma revolução comunista sem o enfrentamento da questáo agrária: (1) expropriação da propriedade territorial e emprego da renda e proveito do Estado; (2) imposto fortemente progressivo; (3) aboliçáa do direito de herança; (4) confisco da propriedade de todos os emigrantes e sediciosos; (5) centralização do crédito nas mãos do Estado, por meio de um banco nacional com capital do Estado e com o monopólio; (6) centralização dos meios de comunicação e transporte nas mãos do Estado; (7) multiplicação das fábricas e dos meios de produção possuídos pelo Estado, o cultivo das terras improdutivas e o aprimoramento do solo em geral, segundo um plano; (8) trabalho obrigatório para todos, estabelecimento de exércitos industriais, especialmente para a agricultura; (9) combinação da agricultura com as indústrias manufatureiras e abolição gradual da distinção entre a cidade e o campo, por meio de uma distribuição mais igualitária da população pelo país; (10) educação gratuita para todas as crianças, em escolas públicas, abolição do trabalho infantil nas fábricas. Combinação da educação com a produção industrial. Essas teses continuam atuais em seu sentido genérico, o que devemos 
fazer é atualizar o conteúdo histórico das mesmas.

- As Teses de Abril de Lênin, de 1917. Reconhecendo-se em minoria no Congresso de 1917, e não podendo pensar em golpe de força, Lênin conclui que é preciso ensinar às massas a não mais confiar nos conciliadores e nos partidários da defesa nacional. É preciso explicar, explicar e explicar pacientemente e conclui sobre as tarefas do partido, a saber: realizar o congresso do partido; modificar o programa, principalmente sobre o imperialismo, a respeito da posição diante do Estado e a nossa reivindicação de um Estado comuna; corrigir o programa mínimo já superado, mudar o nome do partido.

- O Programa de 1938, onde Trotsky lança, sustenta e formula as premissas objetivas da revolução socialista. A situação mundial no seu conjunto se caracteriza, antes de tudo, pela crise histórica da direção do proletariado. A premissa econômica da revolução proletária já alcançou há muito o ponto mais elevado que pode ser atingido pelo capitalismo. As forças produtivas da humanidade deixaram de crescer. A revolução ou é mundial ou não existe em um só país.

A Quarta Internacional fundada por Trotsky, com base no Programa de Transição, nos convoca a construir a frente única com base nas reivindicaçôes imediatas, mediatas e históricas dos trabalhadores. $\mathrm{O}$ método proposto por Trotsky apoia-se em três pilares: $O$ problema do governo que se baseia nos partidos, do estado que se baseia nas instituiçóes, e a superaçáo da crise da direção revolucionária do proletariado, que pressupóe estruturas baseadas nas organizaçóes operárias independentes.

A Quarta Internacional não rejeita as reivindicações se elas conservarem força vital e defenderem incansavelmente os direitos dos trabalhadores e suas conquistas históricas em um trabalho diário no quadro de uma perspectiva correta, real, ou seja, revolucionária. As palavras de ordem não são isoladas ou um conjunto anárquico de palavras de ordem, mas, sim, um sistema de palavras que leve a classe a seguinte conclusão: que a solução de todos os problemas está na conquista do poder pelo proletariado, o que exige a construção de uma direção revolucionária.

As obras clássicas, escritas em meio à violência da luta de classes, tratam das experiências dos trabalhadores organizados. Isso nos demonstra o que Marx (1987) afirmava como a necessidade de explicar a sociedade e a consciência, pelas contradiçôes da vida material, pelo conflito que existe entre as forças 
produtivas sociais e as relações de produção, como se desenvolvem processos revolucionários.

Uma organização social nunca desaparece antes que se desenvolvam todas as forças produtivas que ela é capaz de conter; Nunca relaçóes novas e superiores se lhe substituem antes que as condiçôes materiais de existência destas relaçóes se produzam no próprio seio da velha sociedade. É por isso que a humanidade só levanta os problemas que é capaz de resolver e assim, numa observação atenta, descobrir-se-á que o próprio problema só surgiu quando as condiçôes materiais para o resolver já existiam ou estavam, pelo menos, em vias de aparecer. Em um caráter amplo, os modos de produção asiático, antigo, feudal e burguês moderno podem ser qualificados como épocas progressivas da formação econômica da sociedade. As relaçóes de produção burguesas são a última forma contraditória do processo de produção social, contraditória não no sentido de uma contradição individual, mas de uma contradição que nasce das condiçóes de existência social dos indivíduos. No entanto, as forças produtivas que se desenvolvem no seio da sociedade burguesa, criam ao mesmo tempo as condiçôes materiais para resolver esta contradição. Com esta organização social termina, assim, a Pré-história da sociedade humana. (MARX, 1987, p. 25).

Portanto, concluo reafirmando que as lutas específicas em torno da Educação estão colocadas no plano mais geral da luta de classe, e que esta luta é permanente, é internacional. Isto porque no plano particular das lutas dos trabalhadores brasileiros o desafio é a unidade, independência de classe (TURRA, 2009), a tomado do poder e o atendimento das reivindicaçôes dos trabalhadores da cidade sobre a reduçáo da jornada de trabalho, sem influenciar nos salários, fim do fator previdenciários, orçamentos para serviços públicos como saúde, educação, segurança, moradia, trabalho com valorização do salário mínimo, defesa de suas organizaçóes opondo-se ao imposto sindical, defendendo a Convenção $1987^{18}$ da Organização Internacional do Trabalho (OIT) e os trabalhadores do campo que reivindicam: delimitação da propriedade privada da terra; a alteração dos índices de produtividade da 
terra; a lei florestal que não sirva aos latifundiários e destrua a natureza; fim do trabalho escravo e o trabalho infantil; pela reforma agrária dos trabalhadores; por trabalho e alimento sadio; luta pela Educaçáo do Campo; luta pela preservaçáo ambiental; por um novo modelo agrícola de base camponesa e familiar; e luta pela soberania nacional.

No plano específico da Educação, recoloco, para concluir, a pertinência das cinco teses sobre educação expostas no início, pois dizem sobre um determinado grau de desenvolvimento da consciência da classe que lutam pelas suas reivindicaçóes dos trabalhadores em geral no Brasil e no mundo. São lutas: para que a escola exerça sua função social segundo os interesses da classe trabalhadora; para que os trabalhadores da educação sejam bem formados, tenham salários dignos, boas condiçôes de trabalho e aposentadoria social pública e militem em organismos de classe com autonomia, independência e liberdade sindical; por programas de estudos relacionados com as transformaçôes do modo capitalista de vida; por financiamento a altura do desafio educacional; por uma gestão e administração da escola para além dos marcos da democracia burguesa, mas, sim, nos marcos da revolução proletária; contra o plano mundial de educação dos organismos internacionais; contra as pedagogias do capital, que estão postas no dia-a-dia da educação em nosso país.

Sendo exata a tese da Revolução Permanente, que se dá, concomitante, com processos contra-revolucionários, reconhecemos, por fim, a necessidade histórica da ofensiva em todos os âmbitos - singular, particular e geral -, ou seja, da luta pelas reivindicaçôes específicas da educação, dos trabalhadores brasileiros em geral, e pelas reivindicaçōes históricas dos trabalhadores no mundo.

[...] conceber a história mundial como avançando sempre regularmente e sem escolhos, sem saltos por vezes gigantescos para trás, é antidialéctico, anticientífico, teoricamente incorrecto." (LENIN, 1977, p. 409).

[...] a revolução social não é uma batalha única, mas uma época com toda uma série de batalhas por todas e cada uma das questôes das transformaçóes econômicas e democráticas, que só terminarão com a expropriação da burguesia. (LÊNIN, 1977, p. 273).

Essa luta ou se dará com os trabalhadores unidos e com independência 
de classe, entendendo a essência econômica do imperialismo, em processos revolucionários permanentes, ou, então, a humanidade permanecerá sob o jugo da fase superior do capitalismo (LÊNIN, 1984), o imperialismo.

\section{Notas}

${ }^{1}$ Educação, Consciência de Classe e Estratégia Revolucionária foi o tema da Mesa Redonda número 3 do V Encontro Nacional de Educação e Marxismo (EBEM), que foi realizada na Universidade Federal de Santa Catarina (UFSC), entre os 11 e 14 de abril de 2011. Compuseram a Mesa os professores: Prof. Dr. Mauro Luis Iasi (UFRJ), Prof. Dr. Edmundo Fernandes Dias (UNICAMP) e Celi Zulke Taffarel (UFBA).

${ }^{2}$ Trotsky (2010) defendeu a teoria da Revolução Permanente como revolução socialista mundial, desde 1906, o que pode ser constatado em seu texto "Balanço e Perspectiva", passando pelas polêmicas com o stalinismo e no interior da Oposição de Esquerda. Ela foi elaborada em um processo vivo da luta de classes tendo como base derrotas e vitórias da classe. Na tese, Trotsky (2010) levantou a hipótese de que o proletariado poderia chegar ao poder mesmo em um país extremamente atrasado, antes do que nos países capitalistas adiantados.

${ }^{3}$ A Comuna de Paris durou de março a junho de 1871.

${ }^{4}$ Ver mais A formação Social da Mente, de Vigotsky (1996), e em Funçôes Psicológicas superiores: origem social e natureza mediada, de Veronezi, Damasceno e Fernandes (2005).

${ }^{5}$ Educação do Campo está dentro da referência marxista, pois surge como crítica à realidade da educação brasileira, particularmente à situação educacional do povo brasileiro que trabalha e vive no/do campo e se insurge contra os pilares centrais do capital a saber: a propriedade privada da terra, o trabalho explorado e o Estado burguês.

${ }^{6}$ Enguita (1985, p. 85), aponta a necessidade, antes de desenvolver uma teoria da educação, de delimitar uma crítica da educação a partir das seguintes questôes: "Qué es, pues para Marx, uma crítica de La educación? En qué sentido podemos hablar de una crítica marxiana de La educación? Qué características tendrá esta crítica?”. Esse sentido da crítica marxista 
é colocado também por Freitas (1995), em seu livro Critica da Didática e da Organização do Trabalho Pedagógico, que destaca seis características da abordagem marxista a questão da análise critica: (1) a crítica tem que se dar por oposição a uma realidade concreta e não a partir de um plano teórico; (2) a crítica tem que ser materialista e não pode ser baseada em "ideais educativos"; (3) a crítica deve conduzir-se sobre o real em dado momento histórico concreto, e deve estar inserida em uma totalidade histórica e social; (4) situa o objeto da crítica dentro do processo de produção e reproduçáo do capital; (5) deve mostrar a relação entre os valores educativos e as condiçôes materiais subjacentes a eles, e contribuir para a destruição de tais bases; (6) trata-se de localizar tendências existentes dentro da própria sociedade atual que permitam prever e delimitar o que serão as tendências futuras, buscando soluçóes por antítese reais nas tendências reais existentes.

${ }^{7}$ Ver mais em Linguagem, Desenvolvimento Humano e Educação, de Alvez et al.

${ }^{8}$ Ver mais em Ligia Martins e Ângelo Abrantes, Relação entre conteúdo de ensino e processo de pensamento. Disponível em: <http://www2.fc.unesp. $\mathrm{br} /$ revista_educacao/arquivos/Relacao_entre_conteudos_de_ensino_e_ processos_de_pensamento.pdf>.

${ }^{9}$ Segundo Lênin (1977, p17.), "Para chegarmos a ser comunistas, temos que enriquecer inevitavelmente a memória [...] o comunista náo passaria de um fanfarrão, se não compreende-se e assimilasse todos os conhecimentos adquiridos".

${ }^{10}$ Farta literatura nos demonstra e explica através da teoria do conhecimento, da lógica e da dialética, que isto não nasce espontaneamente. Exigem a práxis revolucionária, ou seja, a aprendizagem para que se desenvolvam capacidades humanas superiores. Ver mais em: Kosik (1977), em Dialética do Concreto; Cheptulin (1982), em Dialética materialista: categorias e leis da dialética; Kopnin (1978), em A Dialética como lógica e teoria do conhecimento; Davidov (1988), em La ensenanza escolar e el desarrollo psíquico.

${ }^{11}$ Esta posição não anula o fato de que existem outras posições que reputam a outras instituiçóes educativas em uma sociedade, aparecendo com vigor, segundo Freitas (2010, p. 157) "no interior de movimentos sociais, em especial no interior do Movimento dos Trabalhadores Rurais Sem Terra 
(MST)". Isto porque, segundo o autor, "a posse da terra, permite que todo um novo modo de vida seja ensaiado. A solidariedade e a vivência coletiva são uma necessidade vital e a completa ausência do estado abre possibilidades para a criaçáo da vida sob novos valores, na contraditória precariedade em que são lançados seus atores".

${ }^{12}$ A crítica marxista à escola capitalista deverá permitir enfrentar a questão colocada por Freitas (2010, p. 164) nos seguintes termos: “[...] como construir a formaçáo da juventude levando-se em conta a escola como a agência que organiza o acesso às bases das ciências e das artes em ligação com o meio educativo mais amplo e suas lutas, bem como com suas múltiplas agências formadoras. [...] como construir uma unidade para a 'didática socialista' diferente da aula verbalista e que acolha esta malha conceitual?”.

${ }^{13}$ Perguntamo-nos, por exemplo, se é possível entender as guerras e a política atual sem entender a essência econômica do imperialismo. Cada um é a classe em si e para si, aprenderá sobre a essência econômica do imperialismo na luta de classes e só a enfrentará se a compreender. Esse foi o esforço do Lênin para explicar a classe trabalhadora o que ocorria em sua época.

${ }^{14}$ Ver mais em: Ana Carolina Galvão Marsiglia, Relação entre o desenvolvimento infantil e o planejamento de ensino. Disponível em: <http://xa.yimg.com/ kq/groups/23100729/1262288130/name/Quarta+-+10h30_Carol_ Desenvolvimento+e+planejamento_Carol.pdf>.

${ }^{15}$ Ver o site: <http://www.dieese.org.br/esp/salmin.xm>.

${ }^{16}$ No seu interior se trava a luta econômica, política e ideológica entre as classes sociais.

${ }^{17}$ A autocrítica das tendências marxistas na América Latina e a dificuldade de aliar premissas teóricas e programática, a dificuldade de construção da unidade na ação, a dificuldade da auto-determinação, autonomia e independência de classe terão que ser radicalmente enfrentadas em um dos próximos Encontros Brasileiros de Educação e Marxismo.

${ }^{18}$ O Convenção mais importante da OIT, a Convenção 1987, trata da proteção do direitos sindicais, e prevê a liberdade sindical, sindicato desligado do estado, um sindicato livre de patrôes e de autoridades públicas. Ela ainda não foi ratificada pelo Brasil. Na Argentina já foi ratificada essa 
Convenção, desde 1960, assim como no Uruguai, em 1954, e no Paraguai, em 1962. Ver Convenção na integra em: <http://www.ilo.org/public/ portugue/region/ampro/brasilia/info/download/conv_87.pdf>.

\section{REFERÊNCIAS}

ANDERSON, Perry. Consideraçōes sobre o marxismo ocidental. São Paulo: Brasiliense, 1989.

CHEPTULIN, A. Dialética materialista: categorias e leis da dialética. São Paulo: Alfa-Omega, 1982.

DAVIDOV. La ensenanza escolar e el desarrollo psíquico. Moscu: Progresso, 1988.

DAVIES, Nicholas. Financiamento da Educação e seus desafios. Ecos Revista Científica, São Paulo, v. 6, n. 1, jun. 2004. Disponível em: <http://www. redefinanciamento.ufpr.br/antigo/nic2.htm>. Acesso em: 13 set. 2011.

DUARTE, Newton. A individualidade para-si: contribuição a uma teoria histórico-social da formação do indivíduo. Campinas, SP: Autores Associados, 1993.

. Educação escolar, teoria do cotidiano e a escola de Vigotski.

Campinas, SP: Autores Associados, 1996.

. Relações entre Ontologia e Epistemologia e a reflexão filosófica sobre o trabalho educativo. Perspectiva, Florianópolis, SC, v. 16, n. 29, p. 99116, jan./jun. 1998a.

- Elementos para uma ontologia da educação na obra de Demerval Saviani. Cadernos Cedes, Campinas, SP, n. 44, p. 85-106, 1998b.

. Sociedade do conhecimento ou sociedade das ilusôes? Quatro ensaios crítico-dialéticos em filosofia da educação. 1. ed. Campinas, SP: Autores Associados, 2003.

Vigotski e o "aprender a aprender": crítica às apropriaçôes neoliberais e pós-modernas da teoria vigotskiana. 3. ed. Campinas, SP: Autores Associados, 2004a.

(Org.). Crítica ao fetichismo da individualidade. 1. ed. Campinas, SP: Autores Associados, 2004b. 1v. 
ENGELS, Friedrich. A origem da família, da propriedade privada e do Estado. São Paulo Centauro, 2001.

ENGUITA, M. F. Trabajo, escuela e ideologia. Madrid: Ediciones Akal S. A., 1985.

FREITAS, Luiz Carlos. Crítica da didática e da organização do trabalho pedagógico. São Paulo: Papirus, 1995.

. A escola Única dos trabalhadores: explorando a sua construção.

In: CALDART, Roseli (Org.). Caminhos para a transformação da escola. São Paulo: Expressão Popular, 2010.

KOPNIN, Pável V. A Dialética como lógica e teoria do conhecimento. Rio de Janeiro: Civilização Brasiliense, 1978.

KOSIK, Karel. Dialética do Concreto. Rio de Janeiro: Paz e Terra, 1977.

LIMA; Katia. Contra reforma na educação superior: de FHC a Lula. São Paulo: Xamã, 2007.

LÊNIN, Vladimir I. Que Fazer? Problemas candentes do nosso movimento. 2. ed. Lisboa: Ediçóes Avante!, 1978.

. Obras Escolhidas. Lisboa: Edições Avante!; Moscou: Edições Progresso. 2v.

. Obras Escolbidas em seis tomos. Lisboa: Editorial Avante!; Moscou:

Edições Progresso, 1984. 2v.

LEONTIEV, Alexei L. Uma contribuição à teoria do desenvolvimento e aprendizagem. In: VIGOTSKY, Lev Semenovich; LURIA, A. R.; LEONTIEV, Aleksei Mikolaievich. Linguagem, desenvolvimento e aprendizagem. São Paulo: Ícone, 2001.

MARTINS, Ligia M.; ARCE, Alessandra. Quem tem medo de ensinar na educação infantil? Em defesa do ato de ensinar. Campinas, SP: Alínea, 2007.

MARX, Karl. Critica ao programa de Gotha. Coimbra, PT: Centelha, 1975. . Prefácio da Contribuição à crítica da economia política. In: MARX, Karl. Contribuição à crítica da economia política. 2.ed. São Paulo: Martins Fontes, 1987.

MARX, Karl; ENGELS, Friedrich. Manifesto do partido comunista. In: MARX, Karl et al. O programa da revolução. Brasilia, DF: Nova Palavra, 2008. 
MARX, Karl; ENGELS, Friedrich. A ideologia alemã: crítica da mais recente filosofia alemã em seus representantes Feuerbach, B. Bauer e Stiner, e do socialismo alemão em seus diferentes profetas (1845-1846). São Paulo: Boitempo, 2007.

MELO, Adriana. A mundialização do educação: consolidação do projeto neoliberal na América Latina, Brasil e Venezuela. Maceió, AL: EDUFAL, 2004.

MONTANO, Carlos; DURIGUETTO, Maria Lúcia. Estado, Classe e Movimento Social. São Paulo: Cortez, 2011.

NEVES; Lúcia M. W. (Org.). A Nova Pedagogia da hegemonia: estratégia do capital para educar o consenso. São Paulo: Xamã, 2005.

PISTRAK, Moisey M. A escola Comuna. São Paulo: Expressão popular, 2009.

PUCCI, Bruno. Teoria crítica e educação. Rio de Janeiro: Vozes, 1995.

SANTOS; Cláudio Félix. Relativismo e escolanovismo na formação do educador: uma análise hstórico-crítica da licenciatura em educação do campo. 2011. Tese (Doutorado em Educação) - Faculdade de Educação, Universidade Federal da Bahia, Salvador, 2011.

SAVIANI, Dermeval. Pedagogia Histórico-crítica: primeiras aproximaçóes. 8. ed. Campinas, SP: Autores Associados, 2003.

. Escola e Democracia. Campinas, SP: Autores Associados; São Paulo: Cortez, 2008.

TROTSKY, Leon. A teoria da Revolução Permanente. São Paulo: Editora José Luiz e Rosa Sudermann, 2010.

TURRA, J. Os desafios atuais para a independência sindical. In: TROTSKY, Leon. Escritos sobre o sindicato. Brasília, DF: Nova Palavra, 2009.

VERONEZI, Rafaela J.; DAMASCENO, Benito P.; FERNANDES, Yvens B. Funçóes Psicológicas superiores: origem social e natureza mediada. Revista de Ciências Médicas, Campinas, SP, v. 14, n. 6, p. 537-541, nov./dez. 2005. Disponível em: <http://periodicos.puc-campinas.edu.br/seer/index.php/ cienciasmedicas/article/view/1147/1122>. Acesso em: 12/09/2011.

VIGOTSKY, Lev Semenovich. A formação social da mente. São Paulo: Martins Fontes, 1996. 
The theses of april 2011 about education, class consciousness and revolutionary strategy

\begin{abstract}
The purpose of the study was to present the main educational problems in Brazil and their possible solutions in the form of five theses. These theses were identified after analysis of the relevant literature. The theses were presented to express the current content of the class struggle, which are points of fierce contention. The conclusion we reached is that the social function of the school is in dispute, as well as the direction of the organization of workers in education, their training, compensation, assistance, healthcare and social security. The understanding of socially useful work as an educational principle and education funding are in dispute. Finally, we present the tactics in the field of permanent revolution, i.e., the tactics for the struggle of the working class in the short, medium and long term to strategically overcome capitalism.
\end{abstract}

Keywords: Education. Class consciousness. Revolution.

Celi Nelza Zulke Taffarel

E-mail: celi.taffarel@gmail.com
Las tesis de abril de 2011

sobre la educación, cons-

ciencia de clase y estrategia revolucionaria

\section{Resumen}

El artículo presenta los principales problemas de la educación en Brasil y sus posibles soluciones en forma de cinco tesis. Estas tesis fueron identificadas a partir de un análisis de la bibliografía pertinente. Las tesis fueron expuestas con el fin de expresar el contenido actual de la lucha de clases. La conclusión a la que llegamos es que la función social de la escuela se encuentra en disputa, así como la dirección de la organización de los trabajadores de la educación, la capacitación, el salário, la asistencia, la salud, el bienestar y la jubilación. Está en debate la comprensión em relación al trabajo socialmente útil como principio educativo y el financiamiento de la educación. Finalmente, se presentan las tácticas en el campo de la revolución permanente, es decir, las tácticas para la lucha a corto, mediano y largo plazo para superar el capitalismo de manera estratégica.

Palabras claves: Educación. Conciencia de clase. Revolución.

Recebido em: 27/2/2012

Versão final recebida em: 28/8/2012

Aprovado em: 31/8/2012 